\title{
ІКТ-ПІДТРИМКА НАУКОВИХ ДОСЛІДЖЕНЬ: ВИКОРИСТАННЯ СОЦІАЛЬНИХ МЕРЕЖ ДЛЯ ВПРОВАДЖЕННЯ РЕЗУЛЬТАТІВ ПЕДАГОГІЧНОГО ЕКСПЕРИМЕНТУ
}

\author{
Людмила Гаврілова \\ доктор педагогічних наук, доцент, \\ завідувач кафедри теорії і практики початкової освіти, \\ ДВНЗ «Донбаський державний педагогічний університет» \\ м. Слов’янськ Донецької області, Україна \\ http://orcid.org/0000-0003-1814-5323 \\ lusjamuz64@gmail.com
}

Анотація. Стаття висвітлює актуальну проблему сучасної вищої школи - всебічне залучення засобів інформаційно-комунікаційних технологій до навчального процесу. Автором проаналізовано питання інформаційно-комунікаційної підтримки наукових досліджень, зокрема використання соціальних мереж для впровадження результатів науково-педагогічної діяльності майбутніх магістрів та докторів філософії галузі знань «Освіта». Теоретичні підвалини дослідження складають зарубіжні й вітчизняні концепції, сучасні стратегії, проекти й ініціативи в галузі інформатизації освіти, наукові розвідки з питань е-освіти, створення і застосування засобів ІКТ в педагогічній діяльності. Нормативно-правове підгрунтя дослідження утворюють європейські та вітчизняні державні документи останніх років («Стратегія розвитку інформаційного суспільства в Україні» (2013), Закон України «Про вищу освіту» (2014), Проект «Цифровий порядок денний для України» (2016), Проект Закону України про внесення змін до Закону України «Про Національну програму інформатизації» (2017) тощо). Автором надано класифікацію наукових мережевих спільнот; узагальнено психологічні, соціальні та педагогічні переваги їхнього застосування в навчанні; розглянуто блоги, форуми і освітні сайти як засоби інтерактивної наукової взаємодії; запропоновано інтернет-сервіси, можливостями яких доцільно користуватися під час організації та проведення наукового дослідження. Визначено основні напрями застосування соціальних мереж для впровадження результатів науково-педагогічної діяльності майбутніх магістрів та докторів філософії в галузі знань «Освіта»: зберігання файлів і посилань на джерела інформації, розповсюдження навчальних матеріалів, створення навчального контенту, організація спільної роботи студентів, ефективна комунікація між студентами й викладачем, створення віртуальних навчальних спільнот, організація та проведення анкетувань, опитувань, контрольних зрізів знань, інших заходів з оцінювання якості навчання.

Ключові слова: соціальні мережі; блог; форум; сайт; ІКТ-підтримка; наукове дослідження; педагогічний експеримент.

Постановка проблеми в загальному вигляді. Сучасне суспільство, яке стрімко еволюціонує й опановує все нові й нові комп'ютерні (електронні, цифрові) технології, наразі осмислюється не лише як інформаційне, а й як мережеве. Соціальні мережі починають впливати на розвиток і реформування освітніх систем у всьому світі. 
ІКТ-підтримка наукових досліджень: використання соціальних мереж для впровадження результатів педагогічного експерименту

На сьогодні складно уявити наукове дослідження, яке проводиться без залучення інформаційно-комунікаційних технологій, ІКТ-супровід або ІКТпідтримка використовуються на всіх етапах наукового пошуку: від початкового етапу збирання й систематизації даних до організації та проведення педагогічного експерименту й аналізу отриманих результатів. Уважаємо, що наразі одним із ефективних засобів здійснення експериментального науковопедагогічного дослідження $є$ залучення соціальних мереж.

Аналіз останніх досліджень і публікацій. Феномен соціальних мереж та їхній вплив на оновлення освітніх технологій активно вивчається сучасними науковцями.

Соціальна мережа (Інтернет сервіс, Social networks service) - це сайт, контент якого створюється зареєстрованими на ньому користувачами, що розміщують інформацію про себе і спілкуються між собою, установлюючи соціальні зв'язки (А. Пелещишин, Ю. Сєров, О. Березко та ін. [1, с. 90]). Завдяки сервісам соціальної мережі учасники створюють віртуальні спільноти (virtual communities, e-communities) - новий тип спільнот, які виникають і функціонують в електронному просторі. Д. Бойд (D. Boyd) та Н. Елісон (N. Ellison) віртуальну соціальну мережу вважають сервісом, який базується на Інтернет-технологіях і дозволяє окремим користувачам:

- створювати відкриті або частково відкриті профілі, тобто набори характеристик і ознак, що описують особистість користувача, наприклад стать, вік, освіту, географічне розташування тощо;

- бачити список своїх комунікацій, тобто власну соціальну мережу (користувачів, із якими вони взаємодіють усередині системи, «друзів»);

- мати доступ до списків комунікацій «друзів», тобто до соціальних мереж інших користувачів усередині системи [2].

О. Тишкова під поняттям «соціальної мережі» розуміє соціальну структуру, яка утворена індивідами або організаціями. Вона відображає різноманітні зв'язки між ними через соціальні взаємостосунки, метою яких $\epsilon$ передача різної затребуваної інформації за допомогою сучасних інформаційних технологій у віртуальному просторі, що набуває все більшої актуальності в інформаційному суспільстві [3].

В останні роки науковці (О. Воронкін [4], Т. Садигова [5] та ін.) аналізують функції соціальної мережі, виокремлюючи серед них комунікаційну, інформаційну, розважальну, функції соціалізації, ідентифікації та самоактуалізації й формування ідентичності (Рис. 1).

О. Воронкін відзначає ще деякі властивості соціальних мереж: формулювання користувачами власних думок та їхня зміна під впливом інших членів соціальної мережі; різний ступінь впливу соціальної мережі на різних користувачів; наявність непрямого впливу в ланцюжку соціальних контактів; існування «лідерів думок»; наявність порога чутливості до зміни думки навколишніх; локалізація груп («за інтересами», із близькими думками); 
ІКТ-підтримка наукових досліджень: використання соціальних мереж для впровадження результатів педагогічного експерименту

урахування чинників «соціальної кореляції»; одночасний вплив зовнішніх чинників (реклама, маркетингові акції, засоби масової інформації тощо); виникнення лавиноподібних ефектів; можливість утворення коаліцій; ігрова взаємодія користувачів; інформаційне управління в соціальних мережах [4].

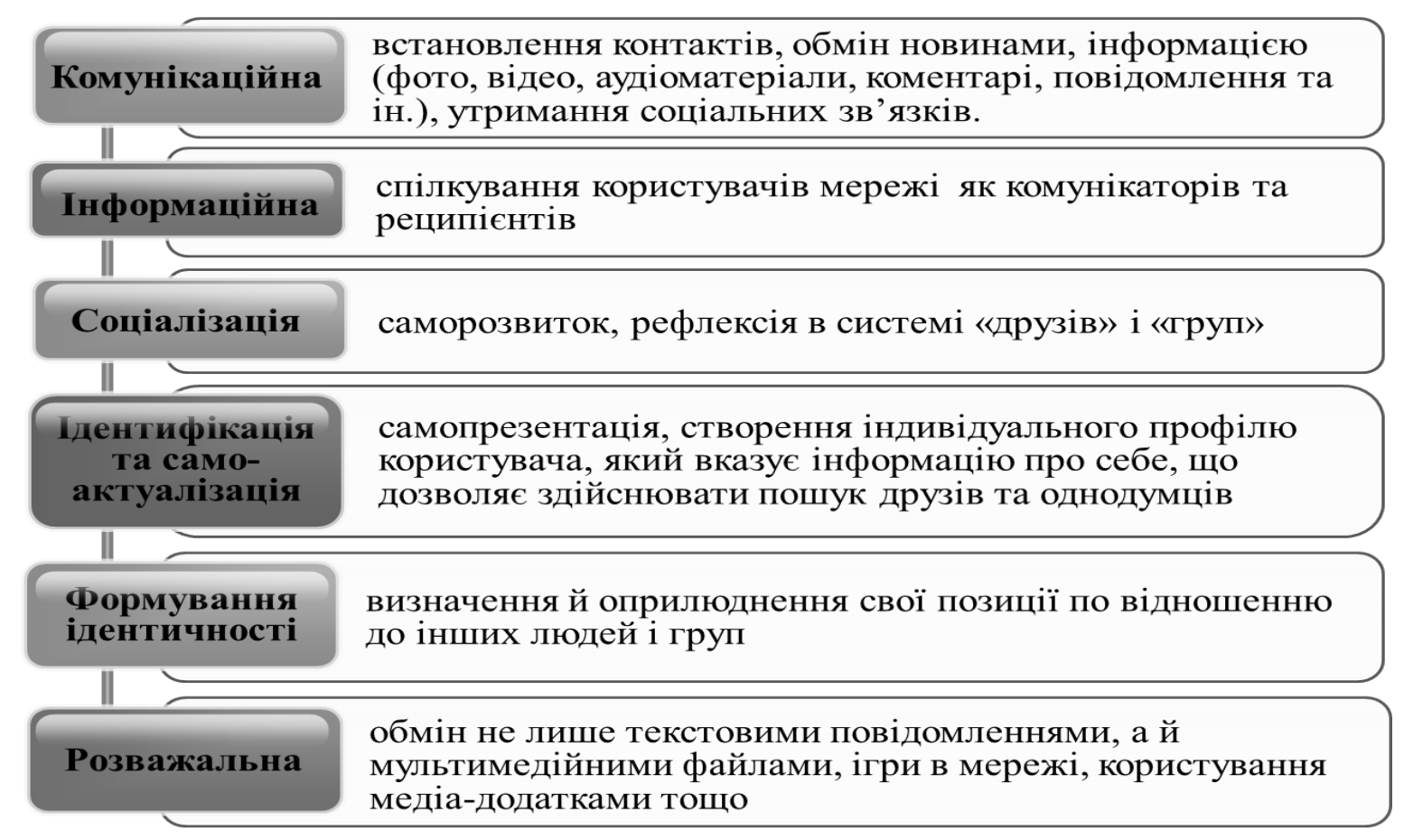

Рис. 1. Функиії соціальної мережі

С. Кирильчук [6] та А. Яцишин [7] узагальнюють основні характеристики функціонування соціальних мереж (Табл. 1):

Таблиця 1.

\section{Основні характеристики функціонування соціальних мереж}

\begin{tabular}{|l|l|}
\hline \multicolumn{1}{|c|}{ Характеристика } & \multicolumn{1}{|c|}{ Зміст } \\
\hline ідентифікація особи & $\begin{array}{l}\text { відомості про особу (навчальний заклад, дата народження, } \\
\text { улюблені книги, фільми тощо) }\end{array}$ \\
\hline присутність на сайті & $\begin{array}{l}\text { можливість дізнатися, хто з користувачів у даний момент є в } \\
\text { мережі, і долучитися до спілкування }\end{array}$ \\
\hline $\begin{array}{l}\text { статус стосунків між } \\
\text { користувачами }\end{array}$ & $\begin{array}{l}\text { визначення стосунків між користувачами (друзі, члени родини, } \\
\text { однокласники тощо) }\end{array}$ \\
\hline комунікація в мережі & $\begin{array}{l}\text { спілкуватися 3 кількома користувачами мережі синхронно та } \\
\text { асинхронно (особистого і групового спілкування, коментарів і } \\
\text { оцінок фото, відео, рефератів, есе тощо) }\end{array}$ \\
\hline міні-групи & $\begin{array}{l}\text { можна створити всередині соціальної мережі об'єднання за } \\
\text { інтересами }\end{array}$ \\
\hline обмін матеріалами & $\begin{array}{l}\text { можливість поділитись з іншими користувачами (документами, } \\
\text { фото, відео, закладками, презентаціями, книгами в цифровому } \\
\text { форматі тощо) }\end{array}$ \\
\hline
\end{tabular}

Професіоналізм педагога: теоретичні й методичні аспекти. - Вип. 7. - Слов’янськ, 2018. 
ІКТ-підтримка наукових досліджень: використання соціальних мереж для впровадження результатів педагогічного експерименту

Крім соціальних мереж існує ще кілька схожих ресурсів, які працюють у форматі Web 2.0. Серед них:

- соціальні закладки - онлайн сервіси, що забезпечують користувачам можливість зберігати, змінювати та ділитися закладками веб-сторінок, об'єднуючи таким чином користувачів зі схожими інтересами (наприклад, pecypc Delicious);

- соціальні каталоги - один зі способів організації та категоризації гіперпосилань на сайти. Це модеровані та тематично погруповані збірки сайтів. Вони орієнтовані на використання в освітньо-науковому та академічному середовищі, дозволяють користувачам працювати 3 базами даних цитат із наукових статей (наприклад, Academic Search Premier, LexisNexis, Academic University, CiteULike).

Формулювання цілей статті (постановка завдання). Мета статті полягає у визначенні можливостей використання соціальних мереж для організації та проведення педагогічного експерименту в наукових дослідженнях магістрантів та майбутніх докторів філософії галузі знань «Освіта».

Теоретичні основи дослідження. Вивчення засобів ІКТ-підтримки науково-педагогічних досліджень, зокрема визначення можливостей використання соціальних мереж для організації та проведення педагогічного експерименту, має нормативно-правове підгрунтя: європейські та вітчизняні державні документи («Стратегія розвитку інформаційного суспільства в Україні» (2013), Закон України «Про вищу освіту» (2014), Проект «Цифровий порядок денний для України» (2016), Проект Закону України про внесення змін до Закону України «Про Національну програму інформатизації» (2017) та ін.).

Важливі теоретичні підвалини дослідження складають зарубіжні й вітчизняні концепції, сучасні стратегії, проекти й ініціативи в галузі інформатизації освіти, наукові розвідки 3 питань е-освіти, створення i застосування засобів ІКТ в педагогічній діяльності (В. Биков, М. Жалдак, М. Лещенко, Л. Петухова, І. Роберт, О. Співаковський, О. Спірін, М. Шишкіна, А. Яцишин, К. Ала-Мутка (K. Ala-Mutka), Д. Белшоу (D. Belshaw), M. Кастельс (M. Castells), C. Доунс (S. Downes), М. Розенберг (M. Rosenberg) тощо).

Результати дослідження. Соціальні мережі для науковців. Аналіз наукової літератури з питань використання соціальних мереж в освіті та науці, огляд Інтернет-ресурсів, зокрема форумів, блогів i сайтів, створених науковцями для підтримки наукової діяльності дозволяє виокремити найпопулярніші серед користувачів соціальні мережі. На сьогодні це:

1. Facebook (https://www.facebook.com) - одна 3 найбільших у світі соціальних мереж, засновником якої є М. Цукенберг (2004 р.), яка була створена як сервіс для студентів деяких американських університетів. Наразі сайт Facebook.com $є$ одним із найбільш відвідуваних у світі. В Україні станом на серпень 2017 року Facebook $є$ найпопулярнішою мережею. Facebook, що дозволяє викладачам університетів створювати навчальні курси для студентів, 
ІКТ-підтримка наукових досліджень: використання соціальних мереж для впровадження результатів педагогічного експерименту

широко використовується в навчанні, особливо закордоном, що доведено результатами соціологічних опитувань.

2. Edutopia (https://www.edutopia.org/) - соціальна мережа, створена для допомоги навчальним закладам розробляти та впроваджувати соціальні медіазасоби в навчальний процес. Головною мотивацією розроблення Edutopia для ïi засновника Дж. Лукаса була «...ізольованість традиційної освіти від реального життя й абстрактність навчальних планів; а також гостра необхідність допомогти викладачам і студентам у пошуку ресурсів і отриманні порад від експертів за межами аудиторії» [3]. Edutopia об’єднує викладачів, що використовують інноваційні засоби навчання в своїй практиці, готових поділитись досвідом 3 іншими.

3. Twitter (https://twitter.com) - мережа мікроблогів, заснована на технології Web 2.0. Її можливості успішно використовуються як засіб інтерактивного навчання іноземних мов, управління проектами, інформаційними системами, що доведено досвідом кількох університетів США.

4. Classroom 2.0 (http://www.classroom20.com/) - освітня соціальна мережа, розроблена С. Харгадоном (2009 р.) на основі інструментів технології Web 2.0. Вона $\epsilon$ найбільш популярною освітньою мережею в США, користуючись якою педагоги отримують необхідну інформацію, плани Інтернетуроків, анонси подій в освіті, підручники та посібники тощо.

5. iEARN (International Education and Resource Network) (https://iearn.org/) - міжнародна освітня та ресурсна глобальна мережа, яка об’єднує 130 країн світу, 30 мов, 2 млн учасників, серед яких більше 40,000 освітян.

Назвемо й вітчизняні соціальні мережі: UkrOpen (https://ukropen.net/), Це Україна (https://xn--v1a.xn--j1amh/), Укрфейс (Ukrface, http://ukrface.com.ua/), Bci mym (https://vsitut.com/) тощо.

Відзначимо, що окрім масових соціальних мереж в Інтернеті функціонують наукові мережеві спільноти для вчених, аспірантів, конкретних науково-дослідних закладів. Серед них, за класифікацією О. Буличової та О. Сюнтюренко [8, с. 30 - 31] (Табл. 2):

Таблиця 2.

\section{Класифікація наукових мережевих спільнот}

\begin{tabular}{|c|c|c|}
\hline $\begin{array}{c}\text { Групи } \\
\text { наукових } \\
\text { мережевих } \\
\text { спільнот }\end{array}$ & $\begin{array}{c}\text { Цілі і завдання } \\
\text { наукових } \\
\text { мережевих спільнот }\end{array}$ & Назви соціальних мереж \\
\hline $\begin{array}{l}\text { Соціальні } \\
\text { мережі, } \\
\text { присвячені } \\
\text { окремим } \\
\text { науковим }\end{array}$ & $\begin{array}{l}\text { - } \quad \text { пошук } \\
\text { однодумців, } \\
\text { дослідників } \\
\text { схожими інтересами; }\end{array}$ & $\begin{array}{l}\checkmark \\
\text { network.com/), } \\
\checkmark \quad \text { Українська асоціація } \\
\checkmark \text { педагогів (http://uasp.org.ua), } \\
\checkmark \quad \text { «Острів Знань» (http://ostriv.in.ua), }\end{array}$ \\
\hline
\end{tabular}


ЛЮДМИЛА ГАВРІЛОВА

ІКТ-підтримка наукових досліджень: використання соціальних мереж для впровадження результатів педагогічного експерименту

\begin{tabular}{|c|c|c|}
\hline $\begin{array}{l}\text { напрямам, } \\
\text { темам }\end{array}$ & $\begin{array}{l}\text { - рецензування } \\
\text { робіт; } \\
\text { - обговорення } \\
\text { результатів } \\
\text { досліджень }\end{array}$ & $\begin{array}{l}\checkmark \quad \text { Асоціація фахівців електронного навчання } \\
\text { e-Learning PRO ( } \underline{\text { http://elearningpro.ru) }}, \\
\checkmark \quad \text { Наукова мережа Scipeople.ru тощо. }\end{array}$ \\
\hline $\begin{array}{l}\text { Наукові й } \\
\text { науково-освітні } \\
\text { мережі }\end{array}$ & $\begin{array}{l}\text { - пошук наукової та } \\
\text { науково-популярної } \\
\text { інформації; } \\
\text { - ї̈ обговорення; } \\
\text { - входження до } \\
\text { наукометричних баз } \\
\text { даних }\end{array}$ & $\begin{array}{lll}\checkmark & \text { Academia.edu (academia.edu); } \\
\checkmark & \text { Academic Earth (academicearth.org); } \\
\checkmark & \text { ResearchGate (www.researchgate.net); } \\
\checkmark & \text { Science and Development } & \text { Network } \\
\text { (www.scidev.net); } & & \\
\checkmark & \text { Українська } & \text { науково-освітня } \\
\text { телекомунікаційна мережа «УРAН» } & \text { (Ukrainian } \\
\text { Research and Academic } & \text { Network, } \\
\text { http://www.uran.net.ua/index.htm). } & \end{array}$ \\
\hline $\begin{array}{l}\text { Соціальні медіа- } \\
\text { сервіси та } \\
\text { соціальні мережі } \\
\text { для вчених }\end{array}$ & $\begin{array}{l}\text { - обмін науковою } \\
\text { інформацією, } \\
\text { зокрема статтями, } \\
\text { матеріалами } \\
\text { конференцій. }\end{array}$ & $\begin{array}{l}\checkmark \\
\text { започатковано видавництвом Thompson Reuters } \\
\checkmark \\
\checkmark \quad \text { мережа } \\
\text { (http://www.citeulike.org/), } \\
\text { видавництвом Springer. }\end{array}$ \\
\hline $\begin{array}{l}\text { Соціальні } \\
\text { мережі, які } \\
\text { вміщують } \\
\text { архіви науково- } \\
\text { дослідної } \\
\text { літератури, } \\
\text { вагомих } \\
\text { наукових } \\
\text { журналів }\end{array}$ & $\begin{array}{l}\text { - розміщення й } \\
\text { надання доступу до } \\
\text { наукових досліджень } \\
\text { та розробок різних } \\
\text { наукових галузей }\end{array}$ & $\begin{array}{ll}\checkmark & \text { Mendeley (http://www.mendeley.com/), } \\
\checkmark & \text { Zotero (https:// www.zotero.org/), } \\
\checkmark & \text { StumbleUpon } \\
\text { (http://www.stumbleupon.com/), } \\
\checkmark & \text { BookMooch (http://bookmooch.com/), } \\
\checkmark & \text { UsefulChem } \\
\text { (http://usefulchem.wikispaces.com/) } \\
\checkmark \quad \text { «Українські науковці у світі» (Ukrainian } \\
\text { Scientists Worldwide, http://usw.com.ua/) }\end{array}$ \\
\hline $\begin{array}{l}\text { Мережі для } \\
\text { майбутніх } \\
\text { науковців } \\
\text { (студентів, } \\
\text { аспірантів) }\end{array}$ & $\begin{array}{l}\text { - заведення } \\
\text { перших професійних } \\
\text { контактів, обмін } \\
\text { iнформацією, } \\
\text { новинами, зокрема } \\
\text { науковими }\end{array}$ & $\begin{array}{ll}\checkmark & \text { Graduates (http://www.graduates.com/), } \\
\checkmark & \text { Postgraduate Toolbox } \\
\text { (http://www.postgraduatetoolbox.net/), } \\
\checkmark & \text { Student (http://www.student.com/), } \\
\checkmark & \text { Educational Networking } \\
(\text { www.educationalnetworking.com/); } \\
\checkmark \quad \text { Campusbug (http://www.campusbug.com/), } \\
\checkmark & \text { TheQuad (https:// thequad.com/berkeley), } \\
\checkmark & \text { ThinkQuest (https://gitso- } \\
\text { outage.oracle.com/thinkquest) та ін. } \\
\checkmark \checkmark \quad \text { Українська освітня соціальна мережа } \\
\text { Studiarium (http://studiarium.net/). }\end{array}$ \\
\hline
\end{tabular}

Соціальні мережі доцільно класифікувати не лише за змістом і цілями, а й за іншими критеріями. На думку М. Семенова [9], їх доцільно розділяти за такими параметрами, як-от:

1) тип (цілі: особисте спілкування, ділове спілкування, відео, аудіо, фото, геолокація, покупки, блогінг, новини, питання-відповідь, закладки, віртуальні світи, тематичні, розваги/знайомства); 
ІКТ-підтримка наукових досліджень: використання соціальних мереж для впровадження результатів педагогічного експерименту

2) відкритість інформації (відкриті, закриті, змішані);

3) географічне охоплення (світ, країна, територіальна одиниця, без регіону - міжнародна);

4) рівень розвитку (веб 1.0 - веб 3.0).

Аналіз вітчизняного й зарубіжного досвіду використання соціальних мереж в освіті (Д. Бойд, Н. Елісон [2], О. Воронкін [4], С. Палій [10] та ін.) дозволяє узагальнити психологічні, соціальні та педагогічні переваги їхнього застосування в навчанні:

1. Задоволення потреби в стимуляції, участі в подіях, досягненнях, отриманні визнання.

2. Знаходження в комфортному та звичному для молоді середовищі.

3. Постійна взаємодія i доступність online учасників навчального процесу.

4. Безкоштовність, функціональність, наявність календарів і спеціальних програм.

5. Реалізація можливостей групової роботи, залучення друзів у соціальній мережі для отримання інформації та вирішення навчальних проблем.

6. Можливість фільтрації інформації, що надходить.

7. Спільне створення учням і викладачем навчального контенту.

8. Різноманітність форм комунікації (вікі-сторінки, форуми, опитування, голосування, коментарі, відправлення персональних повідомлень, наявність стіни, чату тощо).

9. Можливість проведення консультацій і конференцій із використанням сервісів відеозв'язку.

10. Можливість ділитися посиланнями на навчально-методичну літературу, наукові статті, актуальні події, заходи та зустрічі.

11. Широкі демонстраційні можливості (відеоексперименти, лекції, науково-популярні виступи відомих учених).

12. Відсутність географічних кордонів і бар'єрів.

13. Продовження дискусій та обговорень, розпочатих в аудиторії, активне навчання через обговорення.

14. Підвищення рівня комунікативної компетентності викладачів, їхньої соціальної доступності для студентів.

15. Реалізація пізнавальної активності сором'язливих студентів, які зазвичай не виявляють себе на аудиторних заняттях, а в соціальних мережах відчувають себе комфортніше.

16. Залучення до навчального процесу батьків (за необхідністю) $[2 ; 4 ; 10]$.

Блоги, форуми і сайти як засоби інтерактивної освітньої взаємодії. Блог (blog, від web log) (мережевий журнал або щоденник подій) - Інтернет-сервіс, що дозволяє будь-якому користувачеві вести записи з довільної тематики. За аналогією 3 особистими щоденниками блоги називають мережевими щоденниками, проте на відміну від щоденника в блозі записи можна 
ІКТ-підтримка наукових досліджень: використання соціальних мереж для впровадження результатів педагогічного експерименту

коментувати і обговорювати з автором. Фактично блог - це веб-сайт, основний вміст якого складають записи, зображення, мультимедійний контент, що регулярно додаються.

Поширення блогів почалося з 1996 р. У 1999 р. було створено сайт Blogger - першу безкоштовну блогову службу, викуплену компанією Google.

Блоги на відміну від звичайних веб-сайтів мають певні переваги, серед яких можливості:

- швидко і зручно змінювати та налагоджувати інтерфейс, робити дописи, оформлювати їх, додавати зображення, відео, презентації;

- організувати спільну роботу для широкого кола зацікавлених людей (читання, обговорення, додавання записів-постів);

- коментувати записи;

- використовувати мітки (категорії, теги) для пошуку і виведення дописів однієї тематики;

- звернутися до кожного повідомлення, опублікованого всередині блогу, за URL-адресою.

Зручним для користувачів є й можливість підписки на стрічку новин RSS; можливість використання мови $\mathrm{html}$, каскадних стилів та јаva-скриптів; інтеграція з Google і відсутність реклами.

Виокремлюють такі різновиди блогів:

1. За автором (авторами):

- особистий (авторський, персональний) блог, який ведеться однією особою (як правило, його власником);

- «примарний» блог - ведеться від імені чужої особи невизначеною персоною;

- колективний або соціальний блог - ведеться групою осіб за правилами, які визначає власник; організації.

- корпоративний блог - ведеться всіма співробітниками однієї

2. За наявністю та видом мультимедіа:

- текстовий (основним контентом $\epsilon$ тексти);

- фотоблог (основним контентом $є$ фотоматеріали);

- музичний (складається переважно із музичних файлів);

- подкаст і блогкастинг (контент надиктовується та викладається в МР3форматі);

- відеоблог (основним контентом є відеофайли).

3. За особливостями контенту:

- контентний, який публікує авторський контент;

- моніторинговий, основним контентом якого $є$ відкоментовані посилання на інші сайти чи блоги;

- цитатний, який складається з цитат з інших блогів; 
ІКТ-підтримка наукових досліджень: використання соціальних мереж для впровадження результатів педагогічного експерименту

- сплог - спам-блог.

4. За технічною основою:

- Stand-alone блог - блог на окремому хостингу та движку (Content Management Systems, CMS);

- блог на блог-платформі (LiveJournal, LiveInternet та ін.);

- моблог - мобільний веблог, контент якого розміщується в мережі 3 мобільних чи портативних пристроїв [11].

Серед найвідоміших платформ для створення блогів (Рис. 2):

Blogger (https://www.blogger.com) - безкоштовний Інтернет-сервіс для створення і ведення блогів, доступний для користувачів без спеціальних знань із програмування, встановлення та налаштування програмного забезпечення. Сервіс характеризується високою надійністю, необмеженою кількістю блогів, прив'язаних до одного акаунту; характерна також швидка індексація Google, відсутність сторонньої реклами тощо.

LiveJournal (LJ) (https://www.livejournal.com/) - безкоштовна блогплатформа i соціальна мережа для ведення онлайн-щоденників (блогів), заснована 1999 р. Б. Фіцпатриком. Кожен користувач після реєстрації блогу має можливості: писати в ньому записи (особисті, тільки для друзів, для усіх), організовувати групи друзів, створювати спільноти за інтересами, коментувати записи інших користувачів LJ.

WordPress (https://wordpress.co.ua) - система керування вмістом iз відкритим кодом, яка широко використовується для створення блогів та вебсайтів, заснована 2003 p. М. Мулленвігом. На основі WordPress можна конструювати практично будь-які веб-проекти завдяки вбудованій системі тем i плагінів у поєднанні з вдалою архітектурою. Серед переваг використання WordPress: інсталяція на ваш хостинг, що дає повний контроль над блогом, на відміну від безкоштовних блого-сервісів; управління зареєстрованими користувачами; особисті профілі користувачів; легке встановлення та оновлення; високий рівень безпеки тощо [12].

Tumblr. (https://www.tumblr.com) - безкоштовний переважно англомовний ресурс, започаткований 2007 р. Д. Карпом, сервіс мікроблогів, що складається із 7 розділів: Text, Quotes, Photo, Links, Music, Chat, Video, які створюють основні можливості для постів.

Популярні також сервіси Blog.com, Ghost, Type Pad Micro, однак порівняння блог-сервісів за ключовими показниками (відсутність нагромадження додаткових зайвих функцій, простота в налаштуванні й користуванні, зрозумілий інтерфейс, безкоштовне надання більшості послуг) дозволяє надати перевагу платформам Blogger та Tumblr. 


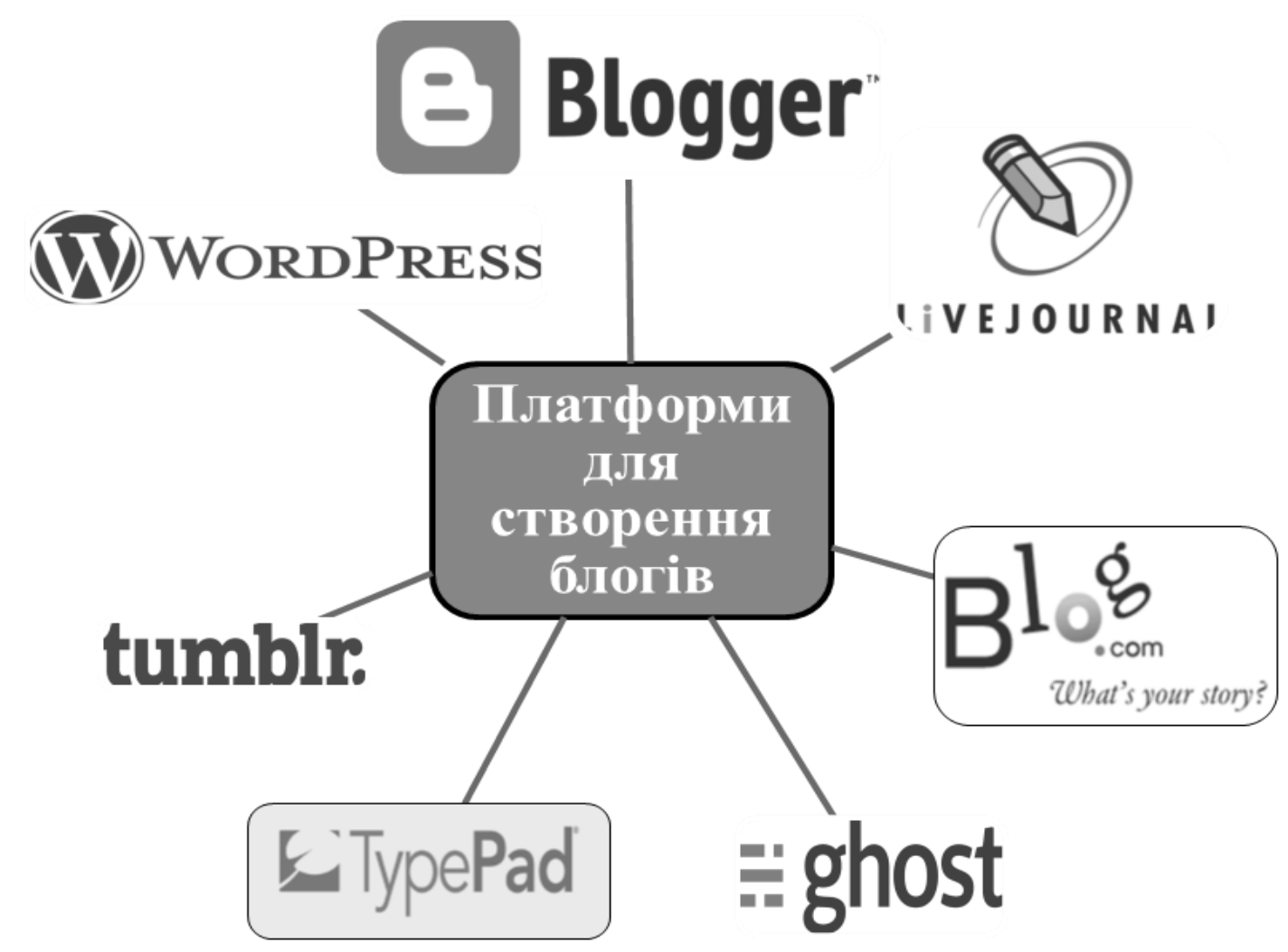

Рис. 2. Найпопулярніші блог-сервіси

Доречно відзначити, що українська блогосфера $є$ важливим середовищем вивчення суспільної думки, вона часто враховується в наукових роботах, що досліджують сучасні глобальні соціальні тенденції. Найпопулярнішою платформою серед українських блогерів $\epsilon$ LiveJournal (кількість українських блогів становить біля 100 тисяч), популярна також англомовна платформа Blogger.com. Серед українських блогерських платформ: Bigmir.net, Meta.ua, Hiblogger.net тощо.

До переваг блогу як інструмента навчання слід віднести наявність зворотного зв'язку між учасниками навчального процесу, чого не вистачає деяким традиційним «архівним» сайтам та паперовим навчальним засобам. Крім того, навчальні матеріали, розміщені в блозі, легко доповнити мультимедійними матеріалами, візуалізуючи теоретичні відомості контентом різних видів.

Сприйняття наукового чи навчального матеріалу, викладеного в блозі, значно підсилює використання списків, підзаголовків (які читають частіше, ніж увесь текст), жирного шрифту для найважливіших положень, додавання фото, графіки, діаграм, відео та іншого мультимедійного контенту, а також спеціального тегу для цитат (blockquote) [13].

Деякі дослідники вважають за доцільне залучати до навчального процесу форуми (онлайн-форуми, веб-форуми) - Інтернет-ресурси, які пропонують набір 
ІКТ-підтримка наукових досліджень: використання соціальних мереж для впровадження результатів педагогічного експерименту

розділів для обговорення і $є$ популярним різновидом спілкування в Інтернеті. Термін відповідає значенню початкового поняття «форум».

Робота форуму полягає в створенні користувачами тем у розділах із подальшим обговоренням цих тем. Окремо взята тема безпосередньо $\epsilon$ тематичною гостьовою книгою. Веб-сервер-форум розділяється так: Розділи > теми > повідомлення. Зазвичай повідомлення несуть інформацію: «автор - тема - вміст - дата/час».

Повідомлення і всі відповіді на нього утворює «вітку» (тему, thread чи топ, topic). За дотриманням правил (відхиленнями від теми, нетикетом) стежать модератори і адміністратори - учасники, наділені можливістю редагувати, переміщати і видаляти чужі повідомлення в певному розділі або темі, а також контролювати до них доступ окремих учасників. Доступ до повідомлень на форумах досить гнучкий: найчастіше необхідна попередня реєстрація, більшість форумів $є$ відкритими, однак існують і закриті, доступ до яких визначається персонально для кожного учасника адміністраторами форуму.

Більшість форумів мають систему особистих повідомлень, що дозволяє зареєстрованим користувачам спілкуватися індивідуально, аналогічно електронній пошті.

Отже, форум - це насамперед інструмент комунікації, а не навчання. Він доречний для спілкування й обміну досвідом між фахівцями чи науковцями.

Окрім форумів, в Інтернеті існують інші види онлайн-спілкування: електронні розсилки, онлайн-чати, онлайн-комунікатори (Skype, ICQ) тощо. Проте вони за різними показниками відрізняються від форумів. Зокрема, електронні розсилки (electronic mailing lists) автоматично доставляють повідомлення в поштову скриньку користувача, а для того щоб отримати повідомлення з форуму, необхідно зайти на веб-сторінку та дізнатися, чи $є$ там нові повідомлення. На відміну від онлайн-комунікаторів для спілкування на форумі не має необхідності одночасного перебування в мережі для обміну повідомленнями. Стосовно е-пошти (e-mail), також відзначимо деякі переваги форуму:

- економія часу, який витрачається при відсиланні електронних листів кожному користувачеві окремо з відповідями на ті самі запитання;

- сприятливі умови для виникнення та швидкого розповсюдження нових ідей, оскільки у форум-спілкуванні бере участь багато людей, на відміну від еmail-листування, яке за формою є спілкуванням двох осіб;

- розвиток професійного спілкування та соціальної взаємодії (учасники форуму створюють соціальні зв'язки з колегами, із якими вони спілкуються онлайн, із різних регіонів країни та зарубіжжя), що значно обмежується в умовах електронної пошти.

Відзначимо, що порівняння форуму з блогом як інструментом навчання, дозволяє виокремити таку перевагу блогу як наявність автора-викладача, який 
ІКТ-підтримка наукових досліджень: використання соціальних мереж для впровадження результатів педагогічного експерименту

професійно організовує процес навчання (на форумі переважає спілкування, наукові чи методичні дискусії).

Для вдосконалення навчально-виховного процесу під час проведення педагогічного експерименту науковцям галузі знань «Освіта» доцільно використовувати й можливості освітнього веб-сайту як одного із різновидів електронних освітніх ресурсів.

Як зазначено в «Положенні про електронні освітні ресурси» [14], освітній веб-ресурс - це складова навчально-виховного процесу, що має навчальнометодичне призначення та використовується для забезпечення навчальної діяльності студентів і вважається одним із головних елементів сучасного інформаційно-освітнього середовища. Точнішим, на нашу думку, є визначенням Г. Стеценка [15], який указує, що освітні веб-ресурси - це інформаційні дані, що можуть бути представлені у вигляді текстових, графічних, звукових, відео форматах або їх комбінацій, які відображають певну предметну галузь освіти та призначені для забезпечення процесу навчання особистості, формування ii професійної компетентності.

Освітній веб-сайт - поняття вужче за попереднє, його почасту поєднують iз більш конкретним поняттям «навчальний веб-сайт» (коли йдеться про групу веб-сторінок, пов'язаних гіперпосиланнями, інформаційне наповнення яких цілком пов'язано з конкретною навчальною дисципліною або іншим елементом змісту навчання). До освітніх веб-сайтів відносять і веб-сайти шкіл, і веб-сайти навчаючих програм, і сайти, які сприяють упровадженню нових форм організації навчального процесу, i сайти для забезпечення навчально-методичного супроводу освітнього процесу. Отже, освітній веб-сайт - це інформаційний ресурс освітнього призначення, реалізований засобами мережевих технологій.

Науковці диференціюють освітні веб-сайти за їннім використанням у різних сферах освіти:

- сайти для дистанційного та очного навчання певним курсам;

- сайти для дослідницької діяльності;

- сайти консультативного призначення;

- сайти віртуальних методичних об'єднань;

- сайти інформаційних Інтернет-проектів;

- сайти навчальних закладів;

- сайти для розповсюдження культурно-освітньої інформації;

- сайти освітньо-довідкового характеру (електронні енциклопедії, сайти-словники, бази даних);

- $\quad$ сайти змішаного типу (Т. Пуніна [16]).

Існує також навчальна преса (сайти педагогічних періодичних видань) i персональні сайти науковців, викладачів, інших представників освіти, які також можуть виконувати освітні функції, якщо вони створені як інформаційні ресурси, призначені для освітнього обігу. 
ІКТ-підтримка наукових досліджень: використання соціальних мереж для впровадження результатів педагогічного експерименту

Відзначимо особливе значення авторських освітніх сайтів для організації та проведення наукового педагогічного експерименту. Як влучно вказують науковці Н. Кіяновська, Н. Рашевська, С. Семеріков [17], на авторських сайтах викладач має змогу надавати відомості про навчальний курс, розміщувати методичні матеріали, проводити інтерактивне спілкування зі студентами.

На допомогу майбутнім науковцям існує велика кількість конструкторів сайтів, що не вимагають спеціальних знань із програмування і надають можливість користувачеві швидко і легко створювати власні сайти. Приміром, за допомогою конструктора сайтів Google (sites.google.com) можна інтегрувати та агрегувати різноманітні дані в одному місці, включаючи відео, слайдшоу, календарі, презентації, вкладення, додатки, текст, надаючи можливість перегляду і редагування цих даних невеликій групі осіб, організації або всім відвідувачам сайту. До того ж сайти Google дозволяють налаштовувати сайт відповідно до власних потреб, обирати тип сторінок (Web-сторінка, оголошення, картотека), централізовано зберігати Web-вміст та автономні файли, $\epsilon$ можливість управління правами доступу до сайту, пошуку змісту на сайтах Google з використанням пошукових технологій Google тощо [17, с. 166].

Використання освітніх сайтів на етапі впровадження результатів педагогічного експерименту дозволяє науковцю увійти до інформаційноосвітнього середовища (IOC) університету, який у сучасній педагогіці (Л. Панченко [18]) розглядається як відкрита, багатовимірна педагогічна реальність, що охоплює психолог-педагогічні умови та сучасні інформаційнокомунікаційні технології і засоби навчання та забезпечує взаємодію і співпрацю, розвиток особистості викладачів та студентів у процесі вирішення основних освітніх завдань.

Висновки 3 дослідження і перспективи подальших розвідок у цьому напрямі. Підсумовуючи огляд соціальних мереж, можливостями яких доцільно користуватися під час організації та проведення педагогічного експерименту наукового дослідження, відзначимо основні напрями їхнього застосування:

- зберігання файлів (підручників, методичних посібників, навчального відео, електронних навчальних засобів) на сервері, надання студентам/учням доступу до них;

- організація і зберігання посилань на джерела інформації (соціальні закладки та каталоги);

- розповсюдження навчальних матеріалів через соціальні мережі;

- самостійне створення навчального контенту, зокрема 3 використанням засобів мультимедіа, зберігання його на сервері;

- організація спільної роботи студентів, ефективна комунікація між студентами й викладачем, запрошення для спілкування фахівців-професорів інших навчальних закладів;

- включення студентів до роботи професійних співтовариств, вихід дискусій за межі аудиторії та навчальної програми; 
ІКТ-підтримка наукових досліджень: використання соціальних мереж для впровадження результатів педагогічного експерименту

- створення віртуальних навчальних спільнот як додаткової до аудиторних занять форми взаємодії студентів із викладачем/учнів з учителем;

- формування й розвиток навичок самоорганізації, взаємодії та співпраці студентів/учнів;

- організація та проведення анкетувань, опитувань, контрольних зрізів знань, інших заходів з оцінювання якості навчання.

Соціальні мережі в діяльності науковця сприяють особистісному розвитку й формуванню інформаційно-комунікаційної компетентності, удосконаленню рівня володіння іноземними мовами, наукового спілкування й консультування.

Не слід забувати про окремі проблеми використання соціальних мереж у навчанні, оскільки для організації та підтримки навчального процесу в умовах безперервного навчання в мережі необхідні значні витрати часу; існує значна кількість факторів, які відволікають студентів від навчальної діяльності у соціальних мережах (розважальний контент, рекламні повідомлення, активна комунікація, інформаційний потік тощо). Крім того обов'язковою умовою повноцінної роботи у соціальних мережах з навчальних аудиторій $\epsilon$ потужний Інтернет.

Використання соціальних сервісів і соціальних мереж на етапі організації педагогічного експерименту та впровадження його результатів у навчальний процес закладу освіти значно впливає на професійний розвиток майбутніх науковців. Зокрема:

1. Використання соціальних мереж у педагогічному експерименті сприяє формуванню цифрової культури майбутніх науковців та їхньої інформаційнокомунікаційної компетентності.

2. Спілкування у віртуальному середовищі стає інструментом професійного розвитку майбутніх магістрів та докторів філософії галузі знань «Освіта».

3. Наукова та науково-педагогічна діяльність учених, пов'язана 3 активним використання ІКТ на етапі впровадження результатів педагогічного експерименту, цілком відповідає сучасним тенденціям інформатизації освіти, концептуальним вимогам Нової української школи та сприяє утворенню ефективного інформаційного середовища вищого навчального закладу, створюючи перспективи для подальшої інформатизації (цифровізації) вітчизняної освіти.

\section{СПИСОК ВИКОРИСТАНИХ ДЖЕРЕЛ}

1. Пелещишин, А. М., Сєров, Ю. О., Березко, О. Л., Пелещишин, О. П., ТимовчакМаксимець, О.Ю. і Марковець, О.В. (2012). Прочеси управління інтерактивними соиіальними комунікаиіями в умовах розвитку інформаиійного суспільства. Львів, Україна: Видавництво Львівська політехніка.

2. Boyd, D., \& Ellison, N. (2007). Social Network Sites: Definition, History, and Scholarship. Journal of Computer-Mediated Communication, 13(1). Retrieved from http://jcmc.indiana.edu/vol13/issue1/boyd.ellison.html 
ІКТ-підтримка наукових досліджень: використання соціальних мереж для впровадження результатів педагогічного експерименту

3. Тишкова, О. (2014). Соціальні мережі як виклик сучасності в освітньому середовищі. Вісник Інституту розвитку дитини. Серія: Філософія, педагогіка, психологія, 34, $63-72$.

4. Воронкин, А. С. (2014). Социальные сети: эволюция, структура, анализ. Образовательные технологии и общество: международный электронный журнал, 17 (1), 650-675. Взято з https://cyberleninka.ru/article/n/sotsialnye-seti-evolyutsiya-struktura-analiz

5. Садыгова, Т. С. (2012). Социально-психологические функции социальных сетей. Вектор науки ТГУ, 3 (10), 192-194. Взято с https://cyberleninka.ru/article/n/sotsialnopsihologicheskie-funktsii-sotsialnyh-setey

6. Кирильчук, С. М. (2015). Застосування соціальних мереж у процесі підготовки майбутніх педагогів професійного навчання. III Всеукраӥнська конференція «Актуальні проблеми сучасної науки та наукових досліджень». Вінниця: ВДПУ ім. М. Коцюбинського. Взято 3 http://konferenzia.ukrainianforum.net/t72-topic

7. Яцишин, А. В. (2014). Застосування віртуальних соціальних мереж для потреб загальної середньої освіти. Інформаційні технології в освіті, 19, 119-126.

8. Булычева, О.С. и Сюнтюренко, О.В. (2016). Национальная информационная инфраструктура: точки роста. Научные и технические библиотеки, 1, 26-33. Взято 3 http://www.gpntb.ru/ntb/ntb/2016/1/ntb_1_2_2016.pdf

9. Семенов, Н. А. (2008). Социальныле сети, перспективы развития и способы монетизации (Часть 1). Взято 3 http://habrahabr.ru/company/SECL_GROUP/blog/22811

10. Палій, С. В. (2013). Соціальні мережі як засіб комунікації електронного навчання. Управління розвитком складних систем, 13, 152-156. Взято 3 http://urss.knuba.edu.ua/files/zbirnyk-13/152-156.pdf
11. Блог.
(б.д.).
Фізмат-Biкinediя.
Взято

http://new.fizmat.tnpu.edu.ua/index.php/\%D0\%91\%D0\%BB\%D0\%BE\%D0\%B3.

12. Система управління блогом, що таке WordPress? (б.д.). Украӥнський WordPress. Взято 3 https://wordpress.co.ua/stvoryty-blog-na-wordpress/3-blog-management-system-wordpress

13. Як створити ефективний навчальний блог. Принципи e-learning. (б.д.). Українська блогосфера. Взято 3 http://blogosphere.com.ua/2009/03/02/how-to-create-effective-educational$\underline{\mathrm{blog} /}$

14. Положення про електронні освітні ресурси (2012, 1 жовтня). Взято 3 http://zakon2.rada.gov.ua/laws/show/z1695-12\#n13

15. Стеценко, Г. В. (2007). Освітні веб-ресурси та їх класифікація. Комп'ютер в школі mа сім'ї, 6 (62), 23-26.

16. Пунина, Т.Г. (2007). Проектирование и размещение в сети Интернет административных сайтов образовательных учреждений. Тамбов, Россия: Педагогический Интернет-клуб. Взято з http://club-edu.tambov.ru/methodic/2007/ppsite/index.html

17. Кіяновська, Н. М., Рашевська, Н. В., і Семеріков, С. О. (2014). Теоретикометодичні засади використання інформаційно комунікаційних технологій у навчанні вищої математики студентів інженерних спеціальностей у Сполучених Штатах Америки. Кривий Ріг, Україна: Видавничий відділ ДВНЗ «Криворізький національний університет».

18. Панченко, Л. Ф. (2010). Інформаційно-освітне середовище сучасного університету. Луганськ, Україна: Вид-во ДЗ «ЛНУ імені Тараса Шевченка».

\section{ИКТ-ПОДДЕРЖКА НАУЧНЫХ ИССЛЕДОВАНИЙ: ИСПОЛЬЗОВАНИЕ СОЦИАЛЬНЫХ СЕТЕЙ ДЛЯ ВНЕДРЕНИЯ РЕЗУЛЬТАТОВ ПЕДАГОГИЧЕСКОГО ЭКСПЕРИМЕНТА}


ЛЮДМИЛА ГАВРІЛОВА

ІКТ-підтримка наукових досліджень: використання соціальних мереж для впровадження результатів педагогічного експерименту

\title{
Людмила Гаврилова
}

доктор педагогических наук, доцент

ГВУЗ «Донбасский государственный педагогический университет»

г. Славянск Донецкой области, Украина

http://orcid.org/0000-0003-1814-5323

lusjamuz64@gmail.com

Аннотация. Статья освещает актуальную проблему современной высшей школы всестороннее привлечение средств информационно-коммуникационных технологий в учебный процесс. Автором проанализированы вопросы информационно-коммуникационной поддержки научных исследований, в частности использование социальных сетей для внедрения результатов научно-педагогической деятельности будущих магистров и докторов философии в области знаний «Образование». Теоретические основы исследования составляют зарубежные и отечественные концепции, современные стратегии, проекты и инициативы в области информатизации образования, научные исследования по вопросам электронного образования, создание и применение средств ИКТ в педагогической деятельности. Нормативно-правовую основу исследования составляют европейские и отечественные документы последних лет («Стратегия развития информационного общества в Украине» (2013), Закон Украины «О высшем образовании» (2014), Проект «Цифровая повестка дня для Украины» (2016), Проект Закон Украины о внесении изменений в Закон Украины «О Национальной программе информатизации» (2017) и др.). Автором предоставлена классификация научных сетевых сообществ; обобщены психологические, социальные и педагогические преимущества их применения в обучении; рассмотрены блоги, форумы и образовательные сайты как средства интерактивного научного взаимодействия; предложены Интернет-сервисы, возможностями которых целесообразно пользоваться во время организации и проведения научного исследования. Определены основные направления применения социальных сетей для внедрения результатов научно-педагогической деятельности будущих магистров и докторов философии в области знаний «Образование»: хранение файлов и ссылок на источники информации, распространение учебных материалов, создание учебного контента, организация совместной работы студентов, эффективная коммуникация между студентами и преподавателем, создание виртуальных учебных сообществ, организация и проведение анкетирования, опросов, контрольных срезов знаний, других мероприятий по оцениванию качества обучения.

Ключевые слова: социальные сети; блог; форум; сайт; ИКТ-поддержка; научное исследование; педагогический эксперимент.

\section{ICT-SUPPORT OF SCIENTIFIC RESEARCHES: USING SOCIAL NETWORKS FOR IMPLEMENTING RESULTS OF PEDAGOGICAL EXPERIMENT}

\author{
Liudmyla Havrilova \\ Doctor of Pedagogical Sciences, Associate Professor, \\ Head of Primary Education Theory and Practice Department, \\ State Higher Educational Establishment "Donbas State Pedagogical University" \\ Sloviansk, Donetsk region, Ukraine \\ http://orcid.org/0000-0003-1814-5323 \\ lusjamuz64@gmail.com
}


IКТ-підтримка наукових досліджень: використання соціальних мереж для впровадження результатів педагогічного експерименту

\begin{abstract}
The article discloses the relevant issue of the higher educational institutions - full involvement of ICT in the educational process. The author has analysed the issue of ICT-support of scientific researches, particularly using of the social networks for implementing the results of scientific and pedagogical activities of prospective Masters and Doctors of Philosophy in the area of knowledge "Education". The theoretical framework of the survey is essentially based on foreign and native concept, modern strategies, projects and initiatives in the sphere of computerization of education, scientific study of the e-learning, designing and implementation of ICT facilities in pedagogical activity. The legal and regulatory framework of the research is set up by European and Ukrainian State documents of the last few years ("The Strategy of Developing Information Society in Ukraine" (2013), Law of Ukraine "On Higher Education" (2014), Project "Digital Agenda for Ukraine" (2016), Draft Law About Amendment of Law of Ukraine "On National Programme of Informatization" (2017), etc.). The author classifies scientific networked societies; compiles psychological, social, and pedagogical advantages of implementing them into the education; considers blogs, forums and educational sites as means of interactive scientific engagement; suggests Internet services that can be implemented while organizing and conducting scientific research. The main directions of using social networks for implementing the results of scientific and pedagogical activity of prospective Masters and Doctors of Philosophy in the area of knowledge "Education" are determined: keeping files and references to the sources of information, dissemination of learning materials, creating new educational content, organizing students' joint work, effective communication between students and university teachers, creating new virtual educational communities, organizing and conducting questionnaire, surveys, test check of knowledge, and other events for assessing the quality of education.
\end{abstract}

Key words: social networks; blog; forum; site; ICT-support; scientific research; pedagogical experiment.

\title{
REFERENCES
}

1. Peleshchyshyn, A. M., $\quad$ Sierov, Yu. O., $\quad$ Berezko, O. L., $\quad$ Peleshchyshyn, O. P., Tymovchak-Maksymets, O. Yu., \& Markovets, O. V. (2012). Processes of management of interactive social communications in the conditions of the information society development. Lviv, Ukraine: Vydavnytstvo Lvivska politekhnika.

2. Boyd, D., \& Ellison, N. (2007). Social Network Sites: Definition, History, and Scholarship. Journal of Computer-Mediated Communication, 13(1). Retrieved from http://jcmc.indiana.edu/vol13/issue1/boyd.ellison.html

3. Tyshkova, O. (2014). Social networks as a challenge of modernity in the educational environment. Visnyk Instytutu rozvytku dytyny. Seriia: Filosofiia, pedahohika, psykholohiia, 34, 6372 .

4. Voronkin, A. S. (2014). Social networks: evolution, structure, analysis. Obrazovatel'nye tehnologii i obshhestvo: mezhdunarodnyj jelektronnyj zhurnal, 17 (1), 650-675. Retrieved from https://cyberleninka.ru/article/n/sotsialnye-seti-evolyutsiya-struktura-analiz.

5. Sadigova, T. S. (2012). Socio-psychological functions of social networks. Vektor nauki $T G U, 3$ (10), 192-194. Retrieved from https://cyberleninka.ru/article/n/sotsialno-psihologicheskiefunktsii-sotsialnyh-setey.

6. Kyrylchuk, S. M. (2015). Application of social networks in the process of preparation of future teachers of vocational training. III Vseukrainska konferentsiia "Aktualni problemy suchasnoi nauky ta naukovykh doslidzhen”. Vinnytsia: VDPU im. M. Kotsiubynskoho. Retrieved from http://konferenzia.ukrainianforum.net/t72-topic.

7. Iatsyshyn, A. V. (2014). Application of virtual social networks for the needs of general secondary education. Informatsiini tekhnolohii v osviti, 19, 119-126. 
ІКТ-підтримка наукових досліджень: використання соціальних мереж для впровадження результатів педагогічного експерименту

8. Bulycheva, O. S., \& Sjuntjurenko, O. V. (2016). National information infrastructure: growth points. Nauchnye $i$ tehnicheskie biblioteki, 1, 26-33. Retrieved from http://www.gpntb.ru/ntb/ntb/2016/1/ntb_1_2_2016.pdf.

9. Semenov, N. A. (2008). Social networks, development prospects and ways of monetization (Part 1). Retrieved from http://habrahabr.ru/company/SECL_GROUP/blog/22811

10. Palii, S. V. (2013). Social networks as a means of communicating e-learning. Upravlinnia rozvytkom skladnykh system, 13, 152-156. Retrieved from http://urss.knuba.edu.ua/files/zbirnyk13/152-156.pdf.

11. Blog.

(n.d.).

Fizmat-Vikipediia.

Retrieved

from

http://new.fizmat.tnpu.edu.ua/index.php/\%D0\%91\%D0\%BB\%D0\%BE\%D0\%B3.

12. Blog management system, what is WordRress? (n.d.). Ukrainskyi WordPress. Retrieved from https://wordpress.co.ua/stvoryty-blog-na-wordpress/3-blog-management-system-wordpress

13. How to create an effective training blog. Principles of e-learning. (n.d.). Ukrainska blohosfera. Retrieved from http://blogosphere.com.ua/2009/03/02/how-to-create-effectiveeducational-blog/

14. Regulations on Electronic Educational Resources (2012, October 1). Retrieved from http://zakon2.rada.gov.ua/laws/show/z1695-12\#n13.

15. Stetsenko, H. V. (2007). Educational web resources and its classification. Kompiuter v shkoli ta simi, 6 (62), 23-26.

16. Punina, T. G. (2007). Designing and placing on the Internet the administrative sites of educational institutions. Tambov, Russia: Pedagogicheskij Internet-klub. Retrieved from http://clubedu.tambov.ru/methodic/2007/ppsite/index.html

17. Kiianovska, N. M., Rashevska, N. V., \& Semerikov, S. O. (2014). Theoretical and methodical principles of the use of information and communication technologies in the teaching of higher mathematics of the students of engineering specialties in the United States of America. Kryvyi Rih, Ukraine: Vydavnychyi viddil DVNZ "Kryvorizkyi natsionalnyi universytet".

18. Panchenko, L. F. (2010). Information and educational environment of the modern university. Luhansk, Ukraina: Vyd-vo DZ "LNU imeni Tarasa Shevchenka".

Матеріали надійшли до редакції 03.04.2018 p. 